\title{
Editorial
}

\section{EMPLOYMENT EQUITY}

\author{
SHERYL L. BOND*
}

\begin{abstract}
"Whereas the measures taken by Canadian employers to increase the employability and productivity of women, native people, disabled persons, and visible minorities have not yet resulted in nearly enough change in the employment practices which have had the unintended effect of screening a disproportionate number of persons out of opportunities for hiring and promotion...." (p.(i) Equality in Employment, A Royal Commission Report 1984)
\end{abstract}

Through the establishmen't of the Employment Equity Act, 1986, the Government of Canada exercised its responsibility to ensure equitable management of human resources under its jurisdiction. The Federal Contractors Program, an extension through policy of the intent of the Act, was designed, in the first instance, to provide redress to the systemic discrimination experienced by members of the designated target groups, i.e. women, native people, disabled persons and visible minorities, within certain Crown corporations and corporations wholly owned by the Government of Canada. Inadvertently, it captured within its ambit those universities which as employers with over 100 employees, seek to secure contracts equal to or in excess of $\$ 200,000$ with the Federal Government. Whether the original intent was to include the country's major universities or not, universities did become accidental and cautious partners in this social legislation.

Although some universities, through their internal policies or negotiated agreements, had made commitments to employ designated group members, they were unable to demonstrate that those policies had resulted in a reasonable identification and diminution of the powerful constraints affecting the participation of these persons as both faculty and administrators. With such an unfortunately poor record, the universities were not able to successfully argue for exemption. The consequence of inaction has been the imposed obligation to change employment practices.

Given that employment equity legislation is a reality, what does it mean and what will be its impact? Judge Rosalie Abella, in a recent address to a meeting of senior academic women administrators, paraphrased her Commission's definition, "Employment equity is the design of employment practices which ensure that no one is denied opportunity for reasons that have nothing to do with inherent ability." She went on to point out that, to create equality of employment, it must be

*Sheryl L. Bond, Director, Office of Higher Education Management, University of Manitoba. 
acknowledged that not all people are the same and, in accepting the differences, provision has to be made for different treatment. Treating all people the same is not employment equity. It is no longer even considered an acceptable response to overcoming systemic barriers to the equal participation of all segments of society in the labour force.

The impact of employment equity on the university can only be a matter of informed conjecture. Already reeling from the impact of other governmental legislation including pay equity, revision to pension plans, the real or potential abolition of mandatory retirement, coupled with severe budget constraint, low attrition and few new tenure track appointments, the university has been faced with demands for doing more, better, and with less.

Administrators responsible for sustaining the environment in which the academic enterprise can, during these times, survive if not flourish, immediately have to respond to the need to reassign funds from elsewhere within the institution to support the obligation to employment equity. The obligation imposed by the legislation requires, from universities falling in its ambit, the following:

- communication by the organization's chief executive officer to employees, unions and/or employee associations of the commitment to achieve equality in employment through the design and implementation of an employment equity plan;

- assignment of senior personnel with responsibility for employment equity;

- collection and maintenance of information on the employment status of designated group employees, by occupation and salary levels and in terms of hiring, promotions and termination in relation to all other employees;

- analysis of designated group representation within the organization in relation to their representation in the supply of qualified workers from which the contractor may reasonably be expected to recruit employees;

- elimination or modification of those human resource policies, practices and systems, whether formal or informal, shown to have or likely to have an unfavourable effect on the employment status of designated group employees;

- establishment of goals for the hiring, training and promotion of designated group employees. Such goals will consider projections for hiring, promotions, terminations, lay offs, recalls, retirements and, where possible, the projected availability of qualified designated group members;

- establishment of a work plan for reaching each of the goals;

- adoption of special measures where necessary to ensure that goals are achieved, including the provision of reasonable accommodation as required;

- establishment of a climate favourable to the successful integration of designated group members within the organization;

- adoption of procedures to monitor the progress and results achieved in implementing employment equity;

- authorization to allow representatives of the Canada Employment and Immigration Commission access to the business premises and to the records in order to conduct on-site compliance reviews for the purpose of measuring the progress achieved in implementing employment equity. 
Administrators are also quick to point out the complications arising out of the troublesome seniority questions concerning hiring, promotion and lay-off clauses in negotiated agreements and the potential difficulties of collecting personal information from members of the designated groups. These are economically difficult times but, even during the more affluent periods, employment equity was not a priority. It must be argued that, despite the current circumstances in which universities find themselves, there can be no justification based on financial capacity for absenting ourselves from, or giving only a nominal response to, the elimination of inequality in employment.

A characteristic response from the guardians of institutional integrity is a collective fear that the pursuit of equality will mean diminution of standards. It is in this arena, on the floor of the senate and in council meetings, that the leaders of the universities must present the facts, respond to the critics with information and be vigilant to the differences between real recruitment problems and discrimination on the basis of a group factor. In addition to the leadership required from senior administrators and academics, it is also important to ascertain the facts and, where the information is not complete, develop a data base from which to work. Universities do not currently maintain or have access to the required human resource inventory but, given the availability of both the technology and information systems, the data collection should not be an insurmountable problem. The data which are available from Statistics Canada indicate that the appointment of women faculty has remained basically unchanged over the last five decades. This trend has been curiously resistant to change despite the preparation by graduate schools of increasing numbers of women. According to University Enrolment and Degrees published in 1984 by Statistics Canada, women doctorates in the humanities, social sciences, biochemistry, psychology, biology, and medicine exceeded $30 \%$ and was as much as $50 \%$ in selected fields. Women currently hold $16 \%$ of the full-time academic appointments according to Teachers in Universities published in 1984 by Statistics Canada.

The availability of women doctorates by discipline continues to far exceed the presence of women faculty within the disciplines. To correct this known imbalance, the identification of hiring targets as required by the legislation must, in recognition of the differing rate of production of $\mathrm{Ph}$. D. 's between the designated groups, by discipline and by geographic region, be flexible. Although the principle of flexibility is critical to enhance academic standards, flexibility coupled with conformity to the requirements of the legislation will not be enough to produce significant change to the inequality. Change will require both time and incentives.

Individuals, with a sincere belief that intelligence, ability and skills are not group specific, will have to design and implement the concurrent strategies of removing disincentives to change while creating an array of rewards within the system. Covert and institutionalized disincentives abound, impeding the attractiveness of university careers to member of the designated groups and, thereby, the 
selection of the most qualified faculty from the total population. Among the disincentives to be addressed are the limited number of tenure track appointments, the systematic marginalization of the part-time faculty, and the weighting of selection criteria which favors the traditional male career development model. The often less than supportive environment required to attract the calibre of applicants sought will require attention be paid to spousal placement, parental leave, and sexual harassment policies. Of equal importance is the promulgation of incentives to those already on full-time staff to change the status quo. Incentives to be considered include various forms of financial advantage awarded to deans and department heads who are successful in their attempt to correct inequities. In addition, special funds could be established to bring senior members of the designated groups to the university on visiting lecturerships, research fellowships and research/study leaves. When incentives fail to produce the desired change in employment practices, senior administrators should be prepared to refuse to support recommendations for appointment where the data indicate members of the designated groups are available and when those individuals have not been considered on the short list.

Inequality means that not all potential scholars have had the opportunity for appointment, tenure and promotion. Its consequence is that excellence suffers. It is paradoxical that so much of the literature on discrimination has been contributed by members of the academic community and that the university, while espousing the ideals of liberty, equality and merit, cannot point with pride to its own performance as an employer.

\title{
EQUITÉ DANS L'EMPLOI
}

\author{
SHERYL L. BOND*
}

\begin{abstract}
"Alors que les mesures prises par les employeurs canadiens pour accroître l'emploi et la productivité des femmes, des amérindiens, des handicapés et de certaines minorités n'ont pas encore engendré assez de changements dans les pratiques d'emploi qui ont eu pour effet d'éliminer un nombre disproportionné de candidats aux engagements et promotions..." (p. (i) Égalité en matière d'emploi - Rapport de la Commission royale 1984)
\end{abstract}

En adoptant la Loi sur l'égalité d'emploi, 1986, le Gouvernement du Canada s'est engagé à assurer une gestion équitable des ressources humaines qui relèvent de sa compétence. Le Bill C-62 a d'abord été conçu pour corriger la discrimination systématique dont faisaient l'objet les membres de groupes cibles (les femmes, les

${ }^{*}$ Sheryl L. Bond, Directrice, Office of Higher Education Management, University of Manitoba. 
amérindiens, les handicapés et certains groupes minoritaires) au sein de certaines sociêtés de la Couronne et d'organismes du gouvernement fédéral. Cependant, ce bill a été rédigé de telle façon qu'il touche aussi les universités, employant plus de 100 personnes, qui cherchent à obtenir des contrats du gouvernement fédéral équivalents ou supérieurs à $200000 \$$. Qu'à l'origine on ait eu ou non l'intention d'inclure seulement les grandes universités, toutes les universités du pays sont accidentellement devenues des partenaires réservées dans cette législation sociale.

Bien que quelques universités, au moyen de politiques internes ou d'ententes, aient promis d'engager les membres des groupes mentionnés plus haut, elles n'ont pas pu prouver que leurs politiques s'étaient traduites par une identification et une suppression raisonnable des obstacles à l'engagement de ces personnes en tant que professeurs et administrateurs. Avec un dossier peu convaincant, les universités n'ont pas obtenu d'exemption de se conformer à la loi, et elles sont obligées de changer leurs pratiques d'emploi.

La législation sur l'égalité en matière d'emploi existe. Que signifie-t-elle? Quels sont ses effets ? Récemment, dans un discours prononcé lors d'une rencontre de femmes cadres supérieurs d'université, madame le juge Rosalie Abella a paraphrasé la définition élaborée par sa Commission: "L'égalité en matière d'emploi est une conception des pratiques d'emploi qui garantit que personne ne fera l'objet de discrimination pour des raisons autres que les aptitutes inhérentes à l'emploi." Elle a ensuite souligné que pour créer l'égalité d'emploi, il faut reconnaître que les gens sont différents, accepter ces différences, et prévoir des traitements différents. L'égalité en matière d'emploi ne consiste pas à traiter tout le monde de la même façon; ce n'est même plus un obstacle acceptable à la participation égale de tous les segments de la population active.

On ne peut que faire des suppositions sur l'effet de l'égalité en matière d'emploi sur l'université. En plus d'être déjà ébranlée par d'autres mesures gouvernementales telles que l'égalité salariale, la révision des régimes de retraite et l'abolition réelle ou probable de la retraite obligatoire, auxquelles s'ajoutent de sévères contraintes budgétaires, un faible taux d'attrition et peu d'engagements à des postes permanents, l'université doit faire plus, mieux et avec moins de moyens.

Les administrateurs, responsables du milieu dans lequel l'entreprise universitaire peut survivre sinon s'épanouir, doivent aussi répondre immédiatement au besoin de réallocation interne de fonds étrangers à l'établissement pour répondre à l'obligation d'égalité en matière d'emploi. Voici les tâches à accomplir par les universités touchées par la législation:

- le responsable de l'organisme doit s'engager auprès des employés, des syndicats et des associations d'employés, à concevoir et à mettre en oeuvre un plan pour atteindre l'égalité en matière d'emploi;

- assigner à des cadres supérieurs la responsabilité de l'égalité d'emploi ;

- collecter et mettre à jour les renseignements sur le statut des employés appartenant aux groupes cibles, et, par rapport aux autres employés, les classer par poste, niveau salarial, conditions d'engagement, promotions et mise à pied ; 
- faire une analyse de la représentation des groupes cibles dans l'organisme par rapport à leur représentation dans la réserve de main-d'oeuvre qualifiée où l'employeur recrute normalement son personnel ;

- éliminer ou modifier les politiques, systèmes et pratiques en matière de ressources humaines, officiels ou non, qui apparemment ou probablement auront un effect néfaste sur le statut d'emploi des personnes appartenant aux groupes cibles;

- établir des objectifs d'engagement, de formation et de promotion de ces personnes. Les objectifs doivent tenir compte des prévisions d'emploi, de promotion, de renvoi, de mise à pied, de rappel, de retraite, et si possible, des prévisions de disponibilité de personnes qualifiées appartenant aux groupes cibles;

- établir un plan de travail pour atteindre ces buts ;

- au besoin, adopter des mesures spéciales en vue de garantir que ces buts seront atteints, y compris la prévision d'hébergement ;

- créer un climat favorable à l'intégration des membres des groupes cibles au sein de l'organisme ;

- adopter des procédés de contrôle des progrès et des résultats obtenus dans la mise en oeuvre de la politique d'égalité en matière d'emploi ;

- autoriser les représentants de la Commission d'Emploi et Immigration Canada à visiter les locaux et consulter les dossiers de l'organisme afin d'évaluer les progrès accomplis.

Les administrateurs ne manquent pas non plus de souligner les délicates questions d'ancienneté et les complications qu'elles entraînent lors de la négociation des clauses d'engagement, de promotion et de mise à pied. A cela s'ajoutent les difficultés probables de collecte d'information personnelle sur les membres des groupes cibles. L'égalité d'emploi n'a jamais été prioritaire, que ce soit en période d'abondance, ou de vaches maigres comme c'est le cas actuellement. Il faut insister sur le fait qu'en dépit des circonstances actuelles, les universités ne peuvent d'aucune façon utiliser l'excuse des moyens financiers pour s'abstenir d'éliminer l'inégalité dans l'emploi ou d'y répondre de façon insignifiante.

Tout le monde craint que la poursuite de l'égalité d'emploi risque de faire baisser les standards. Telle est la réponse caractéristique des gardiens de l'intégrité institutionnelle. Dans ce forum, dans les assemblées de professeurs et dans les réunions du conseil, les dirigeants des universités doivent présenter les faits, répondre aux critiques avec information à l'appui, et noter les différences entre les vrais problèmes de recrutement et la discrimination en fonction de certains facteurs. En plus du leadership que l'on exige des cadres supérieurs et des professeurs, il est aussi important qu'ils confirment les faits et, lorsque l'information est incomplète, qu'ils mettent sur pied des bases de données. Actuellement, les universités n'ont pas la liste exigée des ressources humaines, ou n'y ont pas accès; mais, grâce à la nouvelle technologie et aux systèmes d'information, la collecte de données n'est plus un problème insoluble. Les données fournies par Statistique Canada indiquent que l'engagement de femmes professeurs n'a à peu près pas changé depuis 50 ans. Cette tendance a curieusement résisté aux changements en dépit du nombre grandissant de femmes 
diplômées des établissements d'enseignement supérieur. Selon Universités: Inscriptions et grades décernés, publié en 1984 par Statistique Canada, la proportion de détentrices d'un doctorat en humanités, sciences sociales, biochimie, psychologie, biologie et médecine dépassait $30 \%$ et allait même jusqu'à $50 \%$ dans certains domaines. Selon Enseignants dans les universités, publié en 1984 par Statistique Canada, les femmes occupent actuellement $16 \%$ des postes de professeurs à plein temps.

Le nombre de détentrices de doctorat par discipline continue de dépasser de loin le nombre de femmes professeurs dans ces disciplines. Pour corriger le déséquilibre, les objectifs d'engagement requis par la législation doivent être assez flexibles pour tenir compte du taux de production de doctorat, différent d'un groupe à l'autre par discipline et par région. Bien que le principe de la flexibilité soit critique pour l'amélioration des standards universitaires, cette flexibilité et les exigences de la législation ne suffiront pas à corriger l'inégalité de façon significative. Le changement s'opèrera avec du temps et des encouragements.

Tout en sachant bien que l'intelligence, la capacité et les aptitudes ne sont pas spécifiques à un groupe, il faudra concevoir et mettre en oeuvre des stratégies qui, à la fois, anéantissent la résistance au changement et offrent des récompenses à l'intérieur du système. Dissimulées ou évidentes, les mesures décourageantes abondent; elles réduisent l'attrait d'une carrière universitaire pour les membres des groupes cibles, et par là même, les possibilités de sélection des professeurs les plus qualifiés dans l'ensemble de la population. Parmi les points démoralisants à attaquer, on compte le nombre limité d'engagement à des postes permanents, la marginalisation systématique des professeurs à temps partiel et les critères de sélection qui favorisent le modèle traditionnel de carrière masculine. Pour attirer les candidats de qualité, dans un milieu souvent peu accueillant, il faut faire particulièrement attention au placement d'un conjoint, au congé parental et aux politiques contre le harcèlement sexuel. Il ne faudra pas négliger non plus les encouragements à changer le statu quo à l'endroit du personnel déjà à temps plein. Les incitations au changement peuvent prendre la forme d'avantages financiers octroyés aux doyens et aux directeurs de département qui ont réussi à corriger des inégalités. De plus, au moyen de fonds spéciaux, on pourrait amener à l'université les membres qualifiés des groupes cibles en tant que conférenciers invités, chercheurs-boursiers et bénéficiaires de congés de recherche ou d'études. Si les incitations ne produisent pas les changements voulus, les cadres supérieurs devraient être prêts à refuser d'appuyer les recommandations d'engagement lorsque les données indiquent que des membres des groupes cibles sont disponibles et qu'ils n'ont pas été considérés sur la liste restreinte de candidats.

L'inégalité signifie que toutes les personnes compétentes n'ont pas eu l'occasion d'être engagées, d'avoir la permanence et d'être promues. C'est l'excellence qui souffre de cette situation. Il est paradoxal que tant d'écrits sur la discrimination aient été produits par des membres de la communauté universitaire et que l'université, tout en épousant les principes de liberté, d'égalité et de mérite, ne puisse pas montrer avec fierté sa propre performance en tant qu'employeur. 